\title{
Kultur Sekolah Berbasis Adiwiyata di Sekolah Dasar dalam Menguatkan Karakter Peduli Lingkungan
}

\author{
Lilis Febri Ramadhani ${ }^{1}$, lin Purnamasari ${ }^{2}$, Veryliana Purnamasari ${ }^{3}$ \\ ${ }^{123}$ Pendidikan Guru Sekolah Dasar, Fakultas IImu Pendidikan, \\ Universitas PGRI Semarang \\ Email : lilisfebri97@gmail.com ${ }^{1}$, iinpurnamasari@upgris.ac.id ${ }^{2}$, \\ verylianapurnamasari@gmail.com ${ }^{3}$
}

\begin{abstract}
Abstrak
Penelitian ini bertujuan untuk menganalisis kultur sekolah berbasis adiwiyata yang menguatkan karakter peduli lingkungan di SDN Lamper Tengah 02 Semarang. Jenis penelitian yaitu kualitatif dengan pendekatan deskriptif. Sumber data penelitian ini adalah lingkungan sekolah, kepala sekolah, guru dan siswa SDN Lamper Tengah 02 Semarang. Teknik pengumpulan data yang digunakan dalam penelitian ini yaitu observasi, wawancara dan dokumentasi. Keabsahan data mengguanakan triuangulasi. Berdasarkan hasil penelitian dan pembahasan yang telah diuraikan maka dapat ditarik kesimpulan bahwa kultur sekolah berbasis adiwiyata yang meliputi kegiatan rutin, kegiatan spontan, keteladanan, pengondisian, edukatif, partisipasif dan berkelanjutan dapat menguatkan karakter peduli lingkungan yaitu pembiasaan memelihara kebersihan dan kelestarian lingkungan, tempat pembuangan sampah dan tempat cuci tangan, kamar mandi dan air bersih, pembiasaan hemat energi, biopori diarea sekolah, saluran pembuangan air limbah, memisahkan jenis sampah organik dan anorganik, pembuatan kompos dari sampah organik, menangani limbah hasil praktik, adanya alat kebersihan, tandon penyimpanan air, pembiasaan program cinta bersih lingkungan.
\end{abstract}

Kata Kunci : Karakter peduli lingkungan, Kultur sekolah, Adiwiyata.

\begin{abstract}
This research aimed to analyze adiwiyata-based school culture that strengthens the character of environmental care at the Lamper Tengah Elementary School 02 Semarang. This research was qualitative with a descriptive approach. The source of this research data were the school environment, principals, teachers and students of Lamper Tengah Elementary School 02 Semarang. The data collection techniques were observations, interviews and documentation. The validity of the data was triangulation. Based on the results of research and discussion that has been outlined, it can be concluded that the culture of school-based adiwiyata which includes routine activities, spontaneous activities, transparency, conditioning, educative, passive and sustainable participation can strengthen the character of environmental care was habituation to maintain cleanliness and environmental sustainability, disposal of garbage and hand washing, bathroom and water, energy saving habituation, biopori in school area, sewer waste water, separating the type of organic and inorganic waste, making compost from organic waste, handle the waste of the results of the practice, the presence of hygiene tools, Tandon water storage, habituation of clean environment love programs.
\end{abstract}

Keywords: Character care environment, school culture, Adiwiyata 


\section{Pendahuluan}

Tujuan pendidikan yang paling mendasar, menurut Socrates, adalah membentuk peserta didik menjadi "good and smart" yang menjadi insan yang berakhlak mulia atau berbudi luhur serta cerdas, kritis dan kreatif (Djalil, 2006). Pemerintah dan bangsa Indonesia telah menyadari hal tersebut dan menjabarkannya ke dalam Undang-Undang Nomor 20 Tahun 2003 tentang Sistem Pendidikan Nasional (Sisdiknas), khususnya pasal 3 yang berbunyi "Pendidikan nasional berfungsi mengembangkan kemampuan dan membentuk watak serta peradaban bangsa yang bermanfaat dalam rangka mencerdaskan kehidupan bangsa, bertujuan untuk berkembangnya potensi peserta didik agar menjadi manusia yang beriman dan bertagwa terhadap Tuhan Yang Maha Esa, berakhlak mulia, sehat, berilmu, cakap, kreatif, mandiri, dan menjadi warga Negara yang demokratis serta bertanggungjawab".

Berdasarkan amanat undang-undang tersebut, sangatlah jelas bahwa sistem pendidikan nasional berfungsi untuk mengembangkan potensi diri peserta didik untuk memiliki kemampuan yang dilandasi oleh karakter yang kuat, yaitu memiliki keimanan, ketaqwaan, kepribadian, akhlak mulia dan kemandirian (Latif, 2018).

Menurut Undang-Undang Sistem Pendidikan Nasional No.20 Tahun 2003 pasal 1 butir 1, pendidikan adalah: "usaha sadar dan terencana untuk mewujudkan suasana belajar dan proses pembelajaran agar peserta didik secara aktif mengembangkan potensi dirinya untuk memiliki kekuatan spiritual keagamaan, pengendalian diri, kepribadian, kecerdasaan, akhlak mulia, serta keterampilan yang diperlukan dirinya, masyarakat, bangsa dan Negara." Pendidikan nasional bertujuan: "untuk mengembangkan potensi peserta didik agar menjadi manusia yang beriman dan bertakwa kepada Tuhan Yang Maha Esa, berakhlak mulia, cakap, kreatif, mandiri, dan menjadi waarga Negara yang demokratis serta bertanggung jawab" (UU Sisdiknas No. 20 tahun 2003 pasal 3). Pengertian secara khusus, karakter adalah nilai-nilai yang khas baik (tahu nilai kebaikan, mau berbuat baik, nyata berkehidupan baik, dan berdamak baik terhadap lingkungan) yang terpatri dalam diri dan terwujud dalam perilaku. Dalam hubungannya dengan pendidikan, pendidikan karakter dapat dimaknai sebagai pendidikan nilai, pendidikan budi pekerti, pendidikan moral, pendidikan watak, yang bertujuan mengembangkan kemampuan siswa untuk memberikan keputusan baik buruk, memelihara kebaikan, mewujudkan dan menebar kebaikan dalam kehidupan sehari-hari dengan sepenuh hati (Ayu, 2017).

Sehubungan dengan ketetapan UUD dan UU tentang Sisdiknas serta tujuan pendidikan nasional yang telah di tetapkan oleh pemerintah bahwa pendidikan di masa yang akan datang ini harus memiliki mutu dan berkualitas dibanding dengan pelaksanaan pendidikan yang telah berlangsung saat sekarang ini. Maka dari pada itu perlu ditegaskan bahwa Keputusan Presiden RI No 1 Tahun 2010 setiap jenjang pendidikan di Indonesia harus melaksanakan pendidikan karakter

Dalam pendidikan karakter Muslich Masnur (2011:75) Lickona (1992) "menekankan pentingnya tiga komponen karakter yang baik (components of good character), yaitu moral knowing atau pengetahuan tentang moral, moral feeling atau perasaan tentang moral, dan moral action atau perbuatan moral". Hal ini diperlukan agar anak mampu memahami, merasakan dan mengerjakan sekaligus nilai-nilai kebijakan. Pendidikan karakter adalah pendidikan budi pekerti plus, yaitu yang melibatkan aspek pengetahuan (cognitive), perasaan (feeling), dan tindakan (action). Menurut Lickona Thomas, tanpa ketiga aspek ini, maka pendidikan karakter tidak akan efektif (Citra, 2012).

Pendidikan karakter adalah suatu sistem penamaan nilai-nilai karakter yang meliputi komponen pengetahuan, kesadaran atau kemauan, dan tindakan untuk melaksanakan nilainilai tersebut, baik terhadap Tuhan Yang Maha Esa, diri sendiri, sesama, lingkungan, maupun kebangsaan. Pengembangan karakter bangsa dapat dilakukan melalui perkembangan karakter individu seseorang. Akan tetapi, karena manusia hidup dalam lingkungan sosial dan budaya tertentu, maka perkembangan karakter individu seseorang hanya dapat dilakukan dalam lingkungan sosial dan budaya yang bersangkutan. Artinya, perkembangan budaya dan karakter dapat dilakukan dalam suatu proses pendidikan yang tidak melepaskan peserta didik dari lingkungan sosial,budaya masyarakat, dan budaya bangsa.Lingkungan sosial dan budaya bangsa adalah Pancasila, jadi pendidikan budaya dan karakter adalah mengembangkan nilainilai Pancasila pada diri peseta didik melalui pendidikan hati, otak, dan fisik (Omeri, 2015).

Lingkungan adalah bagian dari alam yang mengelilingi manusia. Dalam Undang-Undang Nomor 3 Tahun 2009 tentang perlindungan dan Pengelolaan Lingkungan Hidup didefinisikan bahwa "Lingkungan hidup adalah kesatuan ruang dengan semua benda, daya, keadaan dan makhluk hidup, termasuk manusia dan perilakunya yang memengaruhi alam itu sendiri, 
kelangsungan peri kehidupan, dan kesejahteraan manusia serta makhluk hidup lain" (Prasetyo, 2018:53). Dalam hal ini kelangsungan hidup dan kesejahteraan manusia saling berpengaruh satu sama lain, sehingga dapat memberikan perilaku terhadap alam. Salah satu contoh bencana alam yang terjadi karena ulah manusia yaitu banjir dan tanah longsor. Banjir ini disebabkan karena pembuangan sampah sembarangan. Pada bulan september 2016 lalu, terjadi banjir di Garut karena tata guna lahan yang tidak terkendali dan banyak sampah yang tidak di olah dengan baik hal itu menyebabkan 26 orang meninggal. (Sumber: Prasetyo, 2018:100). Dalam suatu lokalkarya di Semarang,Jawa Tengah, pada tahun 2008, telah didata sejumlah penyebab banjir antara lain yaitu sampah,tata guna lahan di kaligawe, erosi, kawasan kumuh disepanjang sungai, kerusakan bangunan pengendali banjir (Prasetyo, 2018). Oleh karena itu, perlu adanya tindakan preventif untuk meminimalisir hal tersebut terjadi. Maka diharapkan semua manusia harus peduli dengan lingkungan.

Kegiatan peduli lingkungan dapat dilakukan oleh semua manusia, termasuk didalamnya adalah peserta didik untuk menjaga lingkungan tetap bersih dan terhindar dari bencana. Untuk itu diperlukan berbagai usaha untuk membentuk karakter peduli lingkungan pada peserta didik sebagai anggota masyarakat. Salah satunya dapat dilakukan melalui pendidikan. pendidikan merupakan salah satu aspek yang penting dalam membentuk pendidikan karakter. Pendidikan karakter merupakan dinamika pengembangan kemampuan yang berkesinambungan dalam diri manusia untuk mengadakan internalisasi nilai sehingga menghasilkan disposisi aktif dan stabil dalam individu (Su'ud dkk, 2011:19).

Pendidikan karakter terdapat 18 nilai pendidikan karakter yaitu religius, jujur, toleransi, disiplin, kerja keras, kreatif, mandiri, demokratis, rasa ingin tahu, semangat kebangsaan, cinta tanah air, menghargai prestasi, bersahabat/komunikatif, cinta damai, gemar membaca, peduli lingkungan, peduli sosial, tanggung jawab (Zubaedi, 2012:74).

Istilah karakter memiliki beragam definisi tergantung dari sudut pandang yang digunakan oleh seseorang dalam mendefinisikannya. Berkaitan dengan istilah karakter, Ki Hadjar Dewantara (Agus Wibowo, 2013: 9-10) memandang bahwa karakter adalah watak atau budi pekerti di mana gerak pikiran, perasaan, dan kehendak atau kemauan bersatu dan menimbulkan tenaga. Ki Hadjar juga menambahkan bahwa karakter dapat menjadi penanda seseorang sebagai akibat sifat karakter yang konsisten. Winnie dan Ratna Megawangi (Masnur Muslich, 2011: 71) juga menyampaikan bahwa karakter merupakan suatu istilah dari bahasa Yunani "to mark" yang berarti menandai. Istilah karakter ini lebih fokus pada tindakan atau tingkah laku dan dari fokus ini muncul dua pengertian karakter. Pertama, menunjukkan bagaimana seseorang bertingkah laku, apakah termasuk dalam manifestasi perilaku baik atau buruk. Kedua, menunjukkan keterkaitan dengan "personality" di mana orang yang berkarakter, tingkah lakunya sesuai dengan kaidah moral. Berdasarkan beberapa pendapat dapat diketahui bahwa karakter adalah watak yang tercermin dalam tindakan atau tingkah laku sebagai manifestasi dari sifat-sifat jiwa manusia (pikiran, perasaan, dan kehendak) sekaligus penanda kepribadian seseorang yang khas, termasuk kaitannya dalam menyesuaikan diri dengan lingkungan. Selanjutnya, definisi karakter menjadi dasar dalam mendefinisikan pendidikan karakter. Pada tingkat satuan pendidikan termasuk sekolah dasar, pendidikan karakter dilaksanakan berdasarkan penentuan prioritas pengembangan nilai-nilai. Pengembangan nilainilai yang dimaksud lebih menunjuk pada nilai-nilai prakondisi yang telah dikembangkan sebelumnya. Sesungguhnya, prioritas ini didasarkan pada kepentingan dan kondisi satuan pendidikan masing-masing (Afriyeni, 2018).

Sekolah sebagai salah satu tempat yang sangat berperan dalam menerapkan pendidikan karakter. Anak-anak yang bersekolah sebagian besar menghabiskan waktunya di sekolah, sehingga apa yang didapatkan di sekolah akan mempengaruhi karakter peserta didik. Banyak kegiatan yang bisa dikembangkan dalam rangka penerapan pendidikan karakter. Kultur sekolah merupakan salah satu lima aspek yang perlu diperhatikan untuk meningkatkan kualitas sekolah diantaranya yaitu : (1) proses belajar mengajar, (2) kepemimpinan, (3) manajemen sekolah, (4) sarana dan prasarana, (5) kultur sekolah (Ariefa dalam Farida, 2017:3). Dalam aspek yang kelima, kultur sekolah menjadi aspek yang dapat menentukan upaya penguatan karakter peduli lingkungan. Karena mencerminkan perilaku warga sekolah dalam sehari-hari. Dalam nilai karakter peduli lingkungan siswa dalam sekolah dapat diaplikasikan dengan melalui program adiwiyata.

Sekolah Adiwiyata adalah sekolah yang baik dan ideal sebagai tempat memperoleh segala ilmu pengetahuan dan berbagai norma serta etika yang dapat menjadi dasar manusia menuju terciptanya kesejahteraan hidup dan cita-cita pembangunan berkelanjutan (Prasetya, 2018:221). Di SDN Lamper Tengah 02 Semarang, pada gerakan Penguatan Pendidikan 
Karakter terdapat pembentukan karakter peduli lingkungan kepada siswa dilakukan melalui program adiwiyata, dimana dalam program ini peserta didik dituntut untuk mencintai lingkungan salah satunya membuang sampah tidak sembarangan, mampu membedakan sampah organik dan anorganik, menjaga kebersihan sekolah dan lingkungan sekolah, tidak merusak tanaman. Akan tetapi masih terdapat sikap-sikap yang belum mencerminkan karakter peduli lingkungan, seperti terdapatnya daun daun kering disekitar tanaman. Penguatan karakter peduli lingkungan pada anak terjadi dari penanaman dan pengembangan kultur sekolah. Hal ini yang akan menjadikan suatu kebiasaan positif pada anak. Dengan adanya kultur sekolah diharapkan siswa dapat menguatkan karakter peduli lingkungan yang akan menjadikan suatu kebiasaan agar anak menjadi manusia yang bertanggung jawab dan peduli akan lingkungan disekitarnya.

Menurut Ki hajar Dewantara pendidikan yaitu tuntunan di dalam hidup tumbuhnya anakanak yang menuntun kekuatan kodrat yang ada pada anak-anak itu, agar semua orang sebagai manusia dan sebagai anggota masyarakat dapat mencapai keselamatan dan kebahagiaan setinggi-tingginya (Wibowo, 2012:17). Pendidikan menurut Ki Hajar Dewantara merupakan proses pembudayaan yakni suatu usaha memberikan nilai-nilai luhur kepada generasi baru dalam masyarakat yang tidak hanya bersifat pemeliharaan tetapi juga dengan maksud memajukan serta memperkembangkan kebudayaan menuju ke arah keluhuran hidup kemanusiaan. menurut Soegeng (2018:78) pendidikan adalah proses memanusiakan manusia lewat pembudayaan. Dalam hal ini suatu tahap yang dilakukan manusia dengan melalui perasaan dalam mengahargai dan menghormati dengan melalui pembudayaan atau suatu kebiasaan seseorang.

Berdasarkan pendapat diatas dapat disimpulkan bahwa pendidikan adalah proses seseorang dalam mengembangkan kemampuan, sikap dan bentuk perilaku yang menjadikan suatu kebudayaannya. Pendidikan sangatlah penting, karena pendidikan untuk kehidupan yang berlangsung ini. Pendidikan juga digunakan sebagai indikator kemajuan bangsa dalam mendukung pembangunan.

Menurut Su'ud (2011:47) Pendidikan karakter merupakan upaya-upaya yang dirancang dan dilaksanakan secara sistematis untuk membantu siswa memahami nilai-nilai perilaku manusia yang berhubungan dengan Tuhan Yang Maha Esa, diri sendiri, sesama manusia, lingkungan dan kebangsaan yang terwujud dalam pikiran, sikap dan perasaan berdasarkan norma agama, budaya dan adat istiadat. Dengan kata lain perkembangan dan pembentukan karakter memerlukan pengembangan keteladanan yang ditularkan, intervensi melalui proses pembelajaran, pelatihan, pembiasaan terus-menerus dalam jangka panjang yang dilakukan secara konsisten dan penguatan serta harus dibarengi dengan nilai-nilai luhur. Menurut Mahbubi (2012:100) Adapun pendidikan karakter terdapat 18 nilai-nilai yaitu : (1) Religius(2) Jujur(3) Toleransi(4) Disiplin(5) Kerja keras. (6) Kreatif. (7) Mandiri(8) Demokratis(9) Rasa ingin tahu(10) Semangat kebangsaan(11) Cinta tanah air(12) Menghargai prestasi(13) Tindakan yang memperlihatkan rasa senang berbicara, bergaul, dan bekerja sama dengan orang lain. (14) Cinta damai(15) Gemar membaca(16) Peduli lingkungan. (17) Peduli sosial(18) Taggung jawab. Penelitian ini memfokuskan pada salah satu nilai pendidikan karakter yaitu peduli lingkungan. Peduli lingkungan yaitu sikap dan tindakan yang selalu berupaya mencegah kerusakan pada lingkungan alam di sekitarnya, dan mengembangkan upaya-upaya untuk memperbaiki kerusakan alam yang sudah terjadi.

Tabel 1. Indikator Ketercapaian Nilai-Nilai Peduli Lingkungan

\begin{tabular}{cl}
\hline No & \multicolumn{1}{c}{ Indikator Ketercapaian } \\
\hline 1 & Pembiasaan memelihara kebersihan dan kelestarian lingkungan sekolah \\
2 & Tersedia tempat pembuangan sampah dan tempat cuci tangan \\
3 & Menyediakan kamar mandi dan air bersih \\
4 & Pembiasaan hemat energy \\
5 & Membuat biopori diarea sekolah \\
6 & Membangun saluran pembuangan air limbah dengan baik \\
7 & Melakukan pembiasaan memisahkan jenis sampah organik dan anorganik \\
8 & Penugasan pembuatan kompos dari sampah organic \\
9 & Penanganan limbah hasil praktik \\
10 & Menyediakan peralatan kebersihan \\
11 & Membuat tandon penyimpanan air \\
12 & Memprogramkan cinta bersih lingkungan \\
\hline
\end{tabular}

Sumber : Wibowo (2015:167) 
Modal budaya merupakan kepemilikan kompetensi dan pengetahuan kultural yang menuntun selera bernilai budaya dan pola-pola konsumsi tertentu, yang dilembagakan dalam bentuk kualifikasi pendidikan (Kusdaryani dkk, 2016:126) Menurut Seymour dan Sarason (dalam Hanum, 2013) kultur sekolah mempunyai kultur yang harus dipahami dan dilibatkan jika suatu usaha mengadakan perubahan terhadapnya tidak sekedar pencitraan. Dalam hal ini kultur sekolah diharapkan dapat menjadi suatu perilaku yang positif yang memberikan suatu perubahan dan akan menjadikan suatu kebiasaan manusia. Perencanaan dan pelaksanaan pendidikan budaya dan karakter bangsa di lakukan oleh kepala sekolah dan guru secara bersama sama salah satunya yaitu pada pengembangan diri yang dilakukan melalui pengintegrasian sehari-hari yaitu 1) kegiatan rutin, yaitu kegiatan yang dilakukan peserta didik dengan konsisten setiap hari. 2) kegiatan spontan, kegiatan yang dilakukan pada saat itu juga. 3) keteladanan, sikap guru dalam melakukan suatu hal dengan bertujuan memberi contoh kepada peserta didik. 4) pengkondisian, sekolah berusaha mencerminkan kehidupan nilai-nilai yang baik sesuai dengan budaya dan karakter yang diinginkan. (Kemendiknas, 2010:15).

Sekolah Adiwiyata adalah sekolah yang telah menerapkan sistem dengan maksud untuk mewujudkan warga sekolah yang bertanggung jawab dalam upaya perlindungan dan pengelolaan lingkungan hidup melalui tata kelola sekolah yang baik untuk mendukung pembangunan berkelanjutan. Menurut Prasetyo (2018:221) tujuan adiwiyata adalah mewujudkan warga sekolah yang bertanggung jawab dalam upaya perlindungan dan pengetahuan lingkungan hidup melalui tata kelola sekolah yang baik untuk mendukung pembangunan yang berkelanjutan.

Menurut Dinas Permukiman Rakyat, Kawasan Permukiman dan Lingkungan Hidup (2017:8) Pelaksanaan Program Adiwiyata terdapat prinsip-prinsip yaitu : (1) Edukatif, yaitu adiwiyata tidak hanya bermakna pengetahuan tapi juga pada tataran perubahan prilaku berarti membawa suatu perubahan prilaku. Perubahan prilaku tersebut, dilandasi dengan iman, ilmu pengetahuan dan seni. (2) Partisipatif, yaitu komunitas sekolah terlibat dalam manajemen sekolah yang meliputi keseluruhan proses perencanaan, pelaksanaan dan evaluasi sesuai tanggungjawab dan peran. (3) Berkelanjutan, yaitu seluruh kegiatan harus dilakukan secara terencana dan terus menerus secara komprehensif.

Menurut Dinas Permukiman Rakyat, Kawasan Permukiman dan Lingkungan Hidup (2017:9) adapun manfaat program adiwiyata yaitu : (1) Mendukung percepatan pencapaian 8 Standar Nasional Pendidikan (standar isi, proses, kompetensi lulusan, pendidik dan tenaga kependidikan, sarana dan prasarana, pengelolaan pembiayaan, dan penilaian) sebagaimana diatur dalam PP No. 19 tahun 2006 tentang Standar Nasional Pendidikan. (2) Meningkatkan efesiensi penggunaan dana operasional sekolah melalui penghematan dan pengurangan konsumsi dari berbagai sumber daya dan energi. (3) Menciptakan kebersamaan warga sekolah dan kondisi belajar mengajar yang lebih nyaman dan kondusif. (4) Menjadi tempat pembelajaran tentang nilai-nilai pemeliharaan dan pengelolaan lingkungan hidup yang baik dan benar bagi warga sekolah dan masyarakat sekitar. (5) Meningkatkan upaya perlindungan dan pengelolaan lingkungan hidup melalui kegiatan pengendalian pencemaran, pengendalian kerusakan dan pelestarian fungsi lingkungan di sekolah.

\section{Metode}

Jenis penelitian ini adalah kualitatif dengan menggunakan pendekatan deskriptif kualitatif. Tempat penelitian ini dilaksanakan di SD Negeri Lamper Tengah 02 Semarang. Sumber data dalam penelitian ini adalah kepala sekolah, guru kelas, dan siswa kelas IV SD Negeri Lamper Tengah 02 Semarang. Teknik pengumpulan data yang digunakan dalam penelitian ini yaitu observasi, wawancara dan dokumentasi. Teknik keabsahan data menggunakan triangulasi sumber dan data. Teknik analisis data dalam penelitian ini yaitu data reduction, data display dan conclusion drawing/verification. 
IVCEJ, Vol 2 No 2, Tahun 2019

\section{Hasil dan Pembahasan}

a. Pelaksanaan Karakter Peduli Lingkungan Di SDN Lamper Tengah 02 Semarang

Pelaksanaan Karakter Peduli Lingkungan Di SDN Lamper Tengah 02 Semarang

\begin{tabular}{|c|c|}
\hline \multirow{3}{*}{$\begin{array}{l}\text { Pembiasaan } \\
\text { memelihara kebersihan } \\
\text { dan kelestarian } \\
\text { lingkungan }\end{array}$} & Memberikan contoh dan arahan \\
\hline & Membuat regu piket \\
\hline & Memberikan kesadaran \\
\hline \multirow{3}{*}{$\begin{array}{l}\text { Pembiasaan } \\
\text { memelihara kebersihan } \\
\text { dan kelestarian }\end{array}$} & Tempat sampah organik dan anorganik yang \\
\hline & Washtafel yang bersih pada setiap kelas \\
\hline & Terdapat kamar mandi yang bersih dan \\
\hline $\begin{array}{l}\text { Tersedianya kamar } \\
\text { mandi dan air bersih }\end{array}$ & Air bersih yang terpenuhi \\
\hline \multirow{2}{*}{$\begin{array}{l}\text { Pembiasaan hemat } \\
\text { energi }\end{array}$} & Semua warga sekolah saling mengingatkan \\
\hline & Menggunakan energi seperlunya \\
\hline Biopori di area sekolah & Adanya biopori disekolah \\
\hline \multirow{2}{*}{$\begin{array}{l}\text { Saluran pembuangan } \\
\text { air limbah dengan baik }\end{array}$} & Penyaringan air limbah yang baik \\
\hline & Saluran air limbah yang tidak berbau \\
\hline \multirow{2}{*}{$\begin{array}{l}\text { Pembiasaan jenis } \\
\text { sampah organik dan } \\
\text { anorganik }\end{array}$} & Aliran air limbah yang lancar \\
\hline & $\begin{array}{l}\text { Adanya tempat sampah organik dan anorganik } \\
\text { dengan warna yang berbeda-beda }\end{array}$ \\
\hline \multirow[t]{2}{*}{$\begin{array}{l}\text { Pembuatan kompos } \\
\text { dari sampah organik }\end{array}$} & Adanya rumah kompos yang baik \\
\hline & Pembuatan dilakukan oleh semua warga \\
\hline $\begin{array}{l}\text { Penangan limbah hasil } \\
\text { praktik }\end{array}$ & Melalui pembelajran SBdP \\
\hline \multirow{2}{*}{ Adanya alat kebersihan } & Alat kebersihan terdapat pada setiap ruang \\
\hline & Adanya tandon penyimpanan air yang bersih \\
\hline $\begin{array}{l}\text { Membuat tandon } \\
\text { penyimpanan air }\end{array}$ & $\begin{array}{l}\text { Kegiatan regu piket kelas sebelum dan } \\
\text { cocı Inah KRM }\end{array}$ \\
\hline \multirow{2}{*}{$\begin{array}{l}\text { Memprogramkan cinta } \\
\text { bersih lingkungan }\end{array}$} & Kegiatan Jum'at bersih \\
\hline & Penanaman tanaman berkelompok \\
\hline
\end{tabular}

Gambar 1. Bagan Pelaksanaan Karakter Peduli Lingkungan

Berdasarkan gambar diatas dapat dijelaskan bahwa pelaksanaan karakter peduli lingkungan di SDN Lamper Tengah 02 ditemukan bahwa guru memberikan contoh dan arahan, membuat regu piket dan memberikan kesadaran kepada siswa dalam pembiasaan memelihara dan melestarikan lingkungan sekolah. Disekoalh juga terdapat tempat sampah organik dan 
anorganik yang memadai, washtafel yang bersih disetiap kelas.kamar mandi yang bersih dan memadai, air bersih yang terpenuhi. Semua warga sekolah saling mengingatkan dan menggunakan energi seperlunya. Di sekolah juga terdapat biopori. Penyaringan air limbah yang baik, saluran air limbah yang tidak berbau, air limbah yang lancar. Untuk memudahlan siswa tempat sampah organik dan anorganik dengan warna yang berbeda-beda. Di SDN Lamper Tengah 02 juga terdapat rumah kompos yang baik, pembuatan dilakukan oleh semua warga sekolah. Penangan limbah hasil praktik ditemukan yaitu melalui pembelajaran SBdP. Alat kebersihan terdapat pada setiap ruang. Di SDN Lamper Tengah 02 mempunyai tandon air sebagai tempat penyimpanan air yang bersih. Dalam kepedulian lingkungan SDN Lamper Tengah 02 memprogramkan cinta bersih lingkungan yaitu kegiatan regu piket kelas sebelum dan sesudah KBM, Kegiatan jum'at bersih dan penanaman tanaman berkelompok.

a. Kultur Sekolah Berbasis Adiwiyata Di SDN Lamper Tengah 02 Semarang

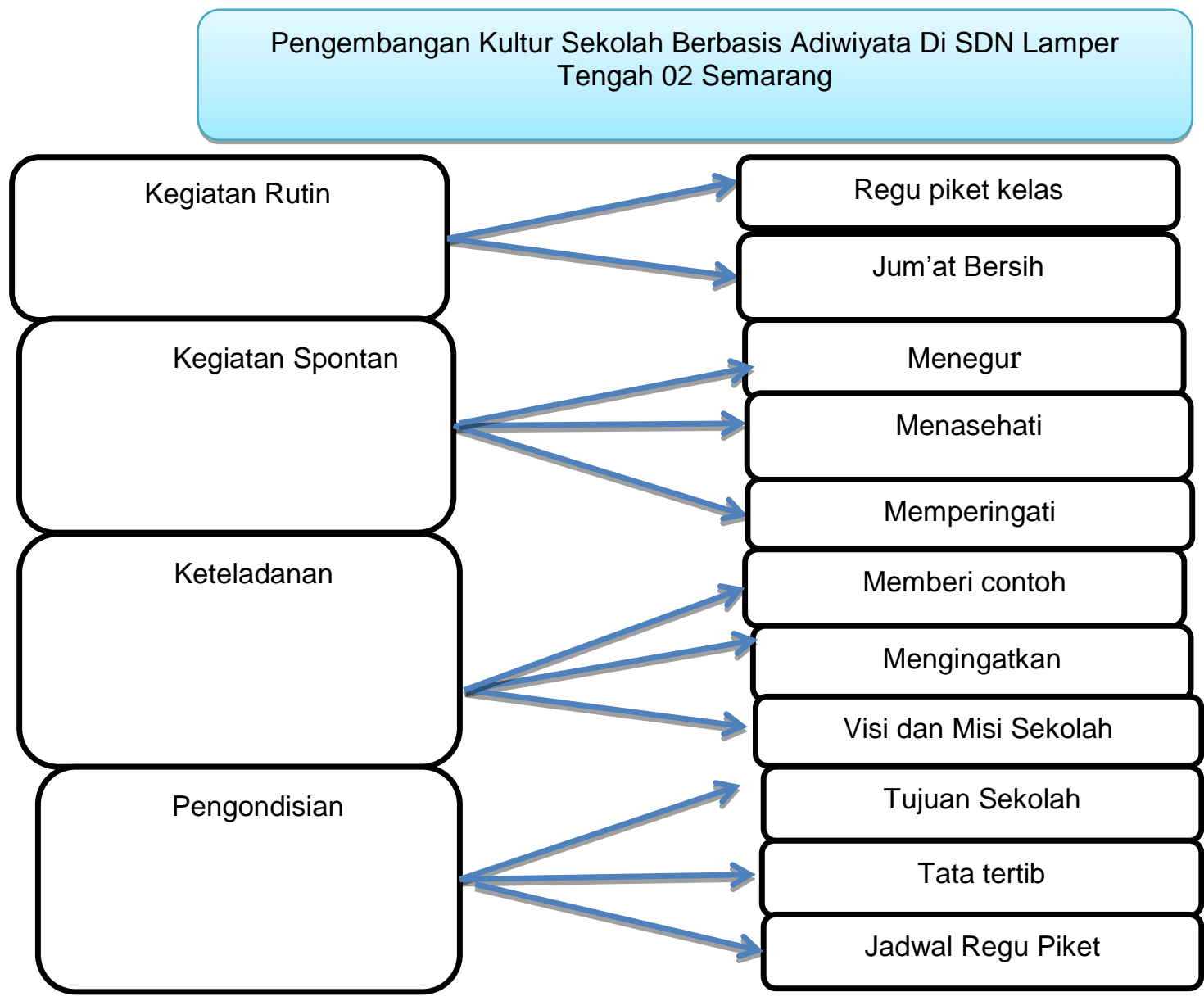

Gambar 2. Kultur Sekolah Berbasis Adiwiyata di SDN Lamper Tengah 02 Semarang

Berdasarkan gambar diatas dapat dijelaskan bahwa kultur sekolah berbasis adiwiyata di SDN Lamper Tengah 02 yaitu dalam kegiatan rutin terdapat regu piket kelas, jum'at bersih.Kegiatan rutin ini dilakukan oleh semua warga sekolah. Kegiatan spontan yang ditemukan di SDN Lamper Tengah 02 yaitu guru menegur siswa jika siswa melakukan kesalahan, guru juga menasehati siswa mengenai sikap kepedulian terhadap lingkungan dan guru juga memberi peringatan pada siswa jika terdapat siswa yang bandel. Bentuk keteladana guru yaitu guru memberi contoh sikap positif kepada siswa mengenai kegiatan peduli lingkungan dan guru selalu mengingatkan siswa unutk selalu menjaga lingkungan tetap bersih. Pengondisian di SDN Lamper Tengah 02 yaitu terdapatnya visi dan misi sekolah, tujuan sekolah, tata tertib dan jadwal regu piket. 


\section{b. Pelaksanaan Program Adiwiyata di SDN Lamper Tengah 02 Semarang}

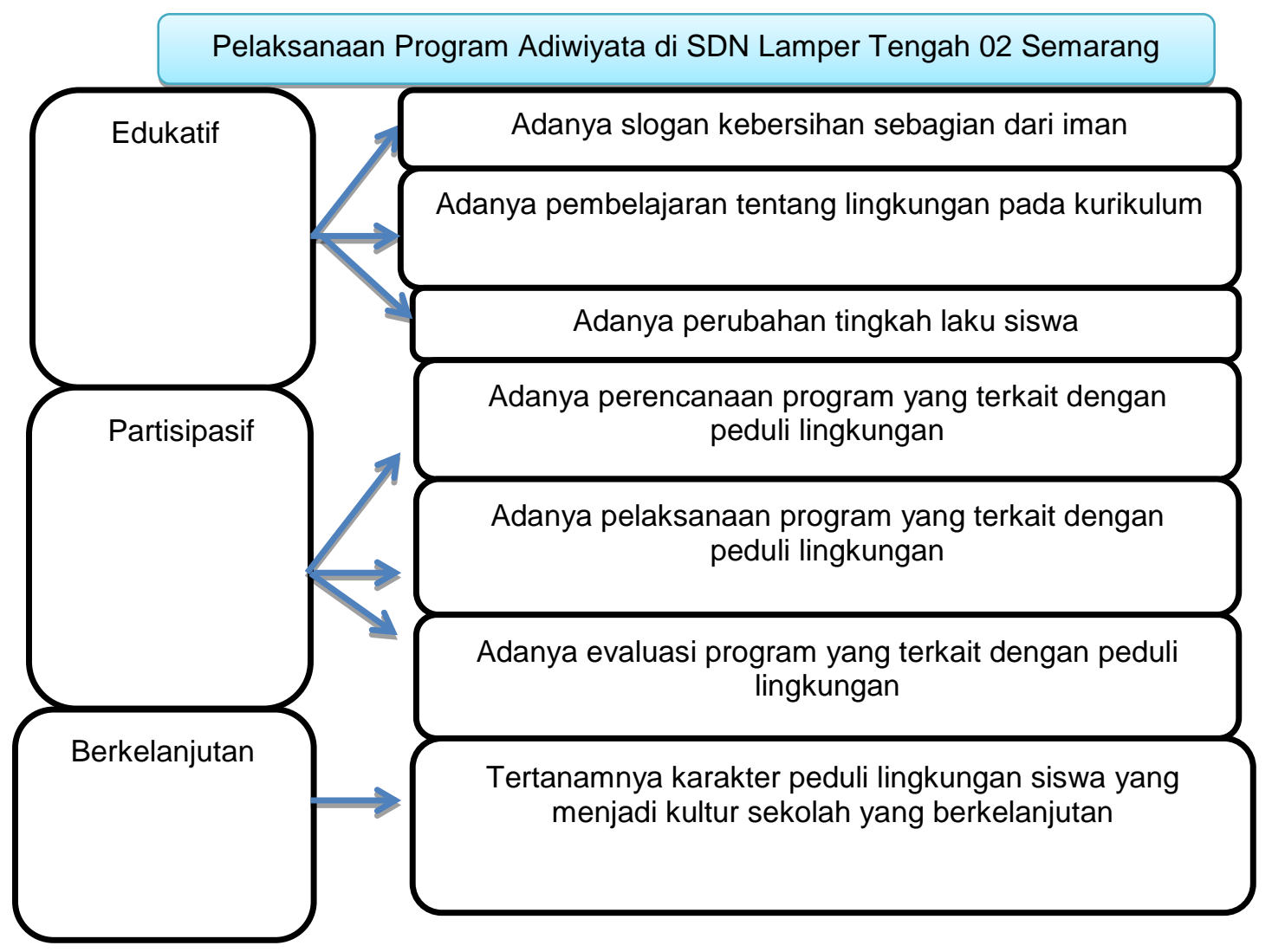

Gambar 3. Pelaksanaan Program Adiwiyata di SDN Lamper Tengah 02 Semarang

Berdasarkan gambar diatas, dapat dijelaskan bahwa program pelaksaan yang ditemukan di SDN Lamper Tengah 02 yaitu (1) edukatif ditemukan yaitu adanya slogan kebersihan sebagian dari iman, danya pembelajaran tentang lingkungan pada kurikulum, adanya perubahan tingkah laku siswa. (2) Partisipasif ditemukan yaitu adanya perencanaan program yang terkait dengan peduli lingkungan, Adanya pelaksanaan program yang terkait dengan peduli lingkungan, adanya evaluasi program yang terkait dengan peduli lingkungan. (3) Berkelanjutan ditemukan yaitu tertanamnya karakter peduli lingkungan siswa yang menjadi kultur sekolah yang berkelanjutan

Pelaksanaan karakter peduli lingkungan di SDN Lamper Tengah 02 Semarang telah tercapai sesuai dengan nilai-nilai indikator peduli lingkungan oleh Wibowo (2015:16) pembiasaan memelihara kebersihan dan kelestarian lingkungan sekolah, tersedianya tempat pembuangan sampah dan tempat cuci tangan, tersedianya kamar mandi dan air bersih, pembiasaan hemat energi, terdapatnya biopori di area sekolah, terdapatnya saluran air limbah yang baik, pembiasaan memisahkan jenis sampah organik dan anorganik, pembuatan kompos dari sampah organik, penanganan limbah hasil praktik, tersedianya peralatan kebersihan, terdapat tandon penyimpanan air, adanya program cinta bersih lingkungan.

Pengembangan Kultur Sekolah Berbasis Adiwiyata Di SDN Lamper Tengah 02 Semarang telah sesuai dengan Kementerian Pendidikan Nasional (2010:15) bahwa kegiatan rutin sekolah merupakan kegiatan yang dilakukan peserta didik secara terus menerus dan konsisten setiap saat, kegiatan spontan yaitu kegiatan yang dilakukan secara spontan pada saat itu juga, keteladanan adalah perilaku dan sikap kepala sekolah, guru dan tenaga pendidikan lainnya dalam memberikan contoh yang baik pada peserta didik, untuk mendukung keterlaksanaan pendidikan budaya dan karakter bangsa sekolah harus dikondisikan sebagai pendukung itu. 
Pelaksanaan Program Adiwiyata di SDN Lamper Tengah 02 Semarang telah tercapai dan sesaui dengan Dinas Permukiman Rakyat, Kawasan Permukiman dan Lingkungan Hidup (2017:8) edukatif yaitu adiwiyata tidak hanya bermakna pengetahuan tapi juga pada tataran perubahan prilaku berarti membawa suatu perubahan prilaku, partisipatif yaitu komunitas sekolah terlibat dalam manajemen sekolah yang meliputi keseluruhan proses perencanaan, pelaksanaan dan evaluasi sesuai tanggungjawab dan peran, berkelanjutan yaitu seluruh kegiatan harus dilakukan secara terencana dan terus menerus secara komprehensif.

\section{Simpulan dan Saran}

Berdasarkan temuan penelitian dan pembahasan dalam bab sebelumnya, maka dapat disimpulkan bahwa sebagai berikut:

Pengembangan kultur sekolah berbasis adiwiyata yang terbentuk di SDN Lamper Tengah 02 meliputi (1) kegiatan rutin, berupa kegiatan piket kelas beregu dan jumat bersih, (2) kegiatan spontan yang berupa menegur siswa yang berperilaku kurang baik terhadap lingkungan dan memberi peringatan pada siswa yang melakukan tindakan yang merusak lingkungan, (3) keteladanan guru, (4) pengondisian melalui tata tertib, jadwal piket, nilai sikap peduli lingkungan, (5) edukatif pembelajaran tentang lingkungan yang terdapat dikurikulum, (6) partisipasif perencanaan, pelaksanaan dan evaluasi pelaksanaan program peduli lingkungan, (7) berkelanjutan dalam menguatkan karakter peduli lingkungan siswa di SDN Lamper Tengah 02 sudah tercapai dalam indikator pendidikan karakter peduli lingkungan diantaranya yaitu pembiasaan memelihara kebersihan dan kelestarian lingkungan sekolah, tempat pembuangan sampah dan tempat cuci tangan yang baik, kamar mandi dan air bersih, pembiasaan hemat energi, biopori diarea sekolah, saluran pembuangan air limbah yang baik, pembiasaan memisahkan jenis sampah organik dan anorganik dengan baik, pembuatan kompos dari sampah organik, menangani limbah hasil praktik dengan baik, peralatan kebersihan yang memadai, tandon penyimpanan air yang bersih, pembiasaan program cinta bersih lingkungan. Penerapan kultur sekolah berbasis adiwiyata ini sangat penting karena dapat membentuk karakter untuk dapat berkembang dan berlangsung di kehidupan sekolah maupun masyarakat, serta hal ini dapat mempersiapkan siswa dalam menghadapi era global di masa yang akan datang

\section{Daftar Pustaka}

Afriyeni, Yeni. 2018. Pembentukan Karakter Anak Untuk Peduli Lingkungan Yang Ada Di Sekolah Adiwiyata Mandiri SDN 6 Pekanbaru. Jurnal Pendidikan Anak Usia Dini, Vol 1, No 2, April 2018

Ayu, Nanda. 2017. Pendidikan Karakter Sebagai Pilar Pembentukan Karakter Bangsa . Jurnal Fakultas IImu Sosial Universitas Negeri Medan Tahun 2017 Vol. 1 No. 1 2017, Hal. 348352

Citra, Yulia . 2012. Pelaksanaan Pendidikan Karakter Dalam Pembelajaran . Jurnal IImiah Pendidikan Khusus Volume 1 Nomor 1 Januari 2012

Dinas Permukiman Rakyat, Kawasan Permukiman dan Lingkungan Hidup (2017:9). 2017. Profil Sekolah Adiwiyata Tahun 2017. Sekretariat Menlhk. Kayong Utara

Hanum, Farida dan Diana. 2013. Kultur Sekolah Dalam Mengembangkan Good School (Sekolah Efektif) Di SMA Negeri 3 Yogyakarta. Jurnal Pendidikan Sosiologi. UNY

Kemendiknas. 2010. Pengembangan Pendidikan Budaya dan Karakter Bangsa Pedoman Sekolah. Jakarta: Badan Penelitian dan Pengembangan Pusat Kurikulum

Kusdaryani, Purnamasari dan Aries Tika Damayani. 2016. Penguatan Kultur Sekolah Untuk Mewujudkan Pendidikan Ramah Anak. UPGRIS 
IVCEJ, Vol 2 No 2, Tahun 2019

Latif, Samal. 2018. Implementasi Pendidikan Karakter di Sekolah dan Perguruan Tinggi Melalui Pembelajaran Aktif. Jurnal Pendidikan Islam Iqra' Vol. 11. Nomor 1 Fakultas Tarbiyah Dan Ilmu Keguruan [Ftik] lain Manado

Mahbubi. 2012. Pendidikan Karakter Implementasi Aswaja sebagai Nilai Pendidikan Karakter. Yogyakarta: Pustaka Ilmu Yogyakarta

Omeri, Nopan. 2015. Pentingnya Pendidikan Karakter Dalam Dunia Pendidikan . Jurnal Manajer Pendidikan, Volume 9, Nomor 3, Juli 2015, hlm. 464-468

Prasetyo, Ketut, dan Hariyanto. 2018. Pendidikan Lingkungan Indonesia. Bandung: PT Remaja Rosdakarya

Republik Indonesia. 2003. Undang - Undang Republik Indonesia Nomor 20 Tahun 2003 Tentang Sistem Pendidikan Nasional. Lembaran Negara RI Nomor 20 Tahun 2003. Sekretaris Negara RI. Jakarta

Soegeng. 2018. Filsafat Pendidikan. Yogyakarta: Magnum Pustaka Utama

Su'ud,Abu. dkk. 2011. Pendidikan Karakter. Semarang: IKIP PGRI Semarang Press

Wibowo,Agus dan Gunawan. 2015. Pendidikan Karakter Berbasis Kearifan Lokal di Sekolah. Yogyakarta: Pustaka Pelajar

Zubaedi. 2012. Desain Pendidikan Karakter. Jakarta: Kencana Prenada Media Group 